Jurnal Indonesia Sosial Teknologi:p-ISSN: 2723 - 6609

e-ISSN :2745-5254

Vol. 2, No.11 November 2021

\title{
ANALISIS PENGARUH KUALITAS SISTEM INFORMASI, KUALITAS INFORMASI DAN PERCEIVED USEFULNESS TERHADAP KEPUASAN PENGGUNA APLIKASI OLIBsIFRS (PSAK) 71 (STUDI PADA BANK PAPUA)
}

\author{
Vicky Arvianto ${ }^{1}$, Wendi Usino ${ }^{2}$ \\ Fakultas Ekonomi dan Bisnis, Universitas Budi Luhur, Jakarta ${ }^{1,2}$ \\ Email:k1k1thea@gmail.com¹, wendy.usino@budiluhur.ac.id ${ }^{2}$
}

\begin{abstract}
Abstrak
Penelitian ini bertujuan untuk menguji dan menganalisis pengaruh Kualitas Sistem Informasi, Kualitas Informasi dan Perceived usefulness terhadap Kepuasan Pengguna aplikasi OlibsIFRS (PSAK) 71 di PT. Bank Papua. Penelitian mengadopsi model kesuksesan sistem informasi DeLone dan McLean yang dikombinasikan dengan model kesuksesan sistem informasi Seddon dan dikolaborasikan dengan metode penelitian kuantitatif. Sampel dalam penelitian ini ditentukan dengan teknik Purposive Sampling dengan metode pengumpulan data dilakukan dengan menggunakan kuesioner google form. Jumlah sampel yang digunakan dalam penelitian yaitu sebanyak 52 orang yang merupakan karyawan pengguna aplikasi OlibsIFRS (PSAK) 71 di PT. Bank Papua. Metode untuk melakukan pengolahan dan analisis data menggunakan Partial Least Square (PLS) dengan bantuan software SmartPLS. Hasil penelitian menunjukan bahwa Kualitas Sistem tidak berpengaruh signifikan dengan kontribusi sebesar 5,1\% terhadap Kepuasan Pengguna, Kualitas Informasi berpengaruh signifikan dengan kontribusi sebesar $\mathbf{2 6 , 0 \%}$ terhadap Kepuasan Pengguna dan Perceived usefulness berpengaruh signifikan dengan kontribusi sebesar 67,9\% terhadap Kepuasan Pengguna aplikasi OlibsIFRS (PSAK) 71 di PT. Bank Papua. Secara simultan variabel Kualitas Sistem, Kualitas Informasi dan Perceived usefulness membentuk R-square senilai $\mathbf{0 , 8 4 6}$ hal ini menandakan variabel Kualitas Sistem, Kualitas Informasi dan Perceived usefulness dari setiap indikator masing-masing variabel secara bersama-sama memberikan pengaruh korelasi yang kuat/signifikan terhadap variabel Kepuasan Pengguna sebesar 84,6\%, sedangkan sisanya sebesar $\mathbf{1 5 , 4 \%}$ dijelaskan oleh variabel dan indikator lain yang tidak dimasukan dalam model penelitian.
\end{abstract}

Kata kunci: Kualitas Sistem Informasi; Perceived usefulness; Kualitas Informasi; PSAK 71; IFRS; Partial Least Square; SmartPLS.

\section{Abstract}

his study aims to examine and analyze the effect of Information System Quality, Information Quality and Perceived usefulness on User Satisfaction of the OlibsIFRS (PSAK) 71 application at PT. Bank Papua. The research adopted the DeLone and McLean information system success model combined with the Seddon information system success model and collaborated with quantitative research methods. The sample in this study was determined by the technique purposive sampling with the data collection method carried out using aquestionnaire google form. The number of 
Analisis Pengaruh Kualitas Sistem Informasi, Kualitas Informasi dan Perceived Usefulness Terhadap Kepuasan Pengguna Aplikasi Olibsifrs (Psak) 71 (Studi pada Bank

Papua)

samples used in this study are 52 people who are employees of users of the OlibsIFRS (PSAK) 71 application at PT. Bank Papua. The method for processing and analyzing data is using Partial Least Square (PLS) with using of software SmartPLS. The results showed that System Quality had no significant effect with a contribution of $5.1 \%$ to User Satisfaction, Information Quality had a significant effect with a contribution of $\mathbf{2 6 . 0 \%}$ to User Satisfaction and Perceived usefulness had a significant effect with a contribution of $\mathbf{6 7 . 9 \%}$ to Application User Satisfaction. OlibsIFRS (PSAK) 71 at PT. Bank Papua. Simultaneously, the variables of System Quality, Information Quality and Perceived usefulness form an R-square of 0,846, this indicates that the variables of System Quality, Information Quality and Perceived usefulness of each indicator of each variable together have a strong/significant

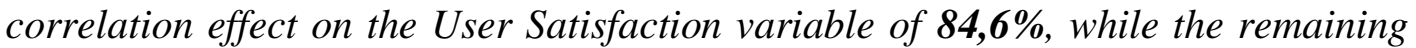
$\mathbf{1 5 , 4 \%}$ is explained by other variables and indicators that are not included in the research model.

Keywords: Information System Quality; Perceived usefulness; Information Quality; PSAK 71; IFRS; Partial Least Square; SmartPLS.

\section{Pendahuluan}

Pada tanggal 24 Juli 2014, IASB menerbitkan IFRS9. Cakupannya yaitu panduan untuk klasifikasi dan pengukuran aset keuangan dengan memperkenalkan fairvalue melalui kategori pendapatan komprehensif lainnya untuk instrumen hutang tertentu. Juga berisi model penurunan baru yang akan membentuk cadangan kerugian sebelum kerugian tersebut terjadi (expected loss). Panduan tersebut juga mencakup panduan lindung nilai (hedging) baru yang dikeluarkan pada bulan November 2013. Perubahan ini cenderung memiliki dampak yang signifikan khususnya pada lembaga keuangan. IFRS 9 secara Internasional berlaku efektif untuk periode tahunan dimulai pada atau setelah tanggal 1 Januari 2018 (Dokumen BRD, 2020).

Berdasarkan Otoritas Jasa Keuangan No. S-78/PB.11/ 2017 tanggal 8 September 2017 perihal "Penerapan PSAK 71 (IFRS 9), telah ditetapkan tanggal efektifnya penerapan PSAK 71 (IFRS 9), yaitu pada tanggal 1 Januari 2020" (Veronica dkk., 2020), dengan penerapan dini diperbolehkan. Penerapan estimasi penurunan nilai secara kolektif adalah dengan menggunakan data historis kerugian kredit selama 5 (Lima) tahun sebelumnya, sehingga estimasi kerugian yang dihasilkan akan lebih andal dan berarti sesuai dengan metode statistik yang akan digunakan.

OlibsIFRS (PSAK) 71 adalah salah satu sistem informasi pelaporan akuntansi yang mengadopsi ketentuan dari PSAK 71 diharapkan mampu menjawab tantangan dalam implementasi PSAK 71 sejalan dengan yang diminta oleh otoritas perbankan. Ditahun 2021, aplikasi OlibsIFRS (PSAK) 71 secara resmi sudah di implementasikan selama lebih dari 1 tahun. Sebagai sistem baru tentunya akan ditemukan kendala-kendala operasional terkait interaksi antara sistem dengan pengguna. Sistem yang kurang stabil seperti munculnya error bugs, penarikan dokumen maupun laporan yang lama, dan tidak adanya fitur di sistem yang dibutuhkan oleh pengguna. 


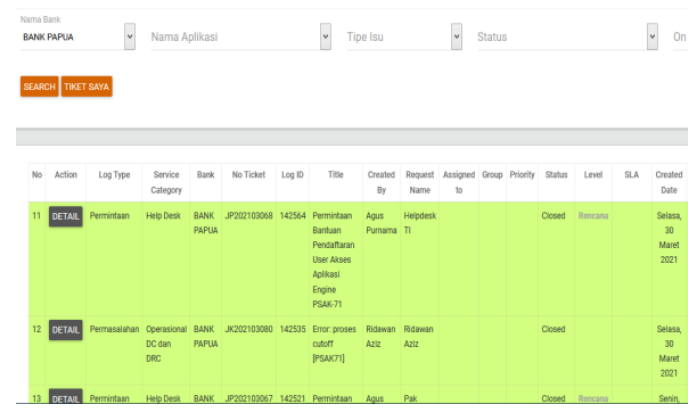

\section{Gambar 1: Daftar Permintaan dan Permasalahan}

Sumber: Aplikasi hepdesk CSS Ver. 3.0 (CSS3)

Berdasarkan permasalahan yang timbul pada gambar diatas, diperlukan pengukuran terhadap kualitas sistem informasi, kualitas informasi yang dihasilkan, dan Persepsi Manfaat (perceived usefulness) dalam penggunaan sistem informasi terhadap Kepuasan Penggunanya.

Pengujian dalam penelitian ini menggunakan modifikasi model kesuksesan sistem informasi dari DeLone dan McLean (DeLone \& McLean, 1992) dan model kesuksesan sistem informasi dari Seddon (Seddon, 1997). DeLone dan McLean menjabarkan elemenelemen dalam model yang digunakan untuk mengukur kesuksesan sistem informasi yang terdiri dari system quality, information quality dan user satisfaction.

Model kesuksesan sistem informasi (Seddon, 1997) merupakan modifikasi dari model sistem informasi (DeLone \& McLean, 1992) dengan mengganti dimensi Penggunaan (use) menjadi Persepsi Kemanfaatan (perceived usefulness). Persepsi kemanfaatan (perceived usefulness) juga merupakan salah satu dimensi dari Technology acceptance model (TAM) yang disusun oleh Davis (Davis, 1989). Persepsi Kemanfaatan (perceived usefulness) didefinisikan sebagai sebuah tingkat yang mengukur kepercayaan seseorang dalam menggunakan sebuah sistem dapat meningkatkan kinerjanya (Davis, 1989).

Mengacu dari penelitian sebelumnya yang dilakukan oleh (Younes dkk., 2013); (Pratomo, 2016); ( $\underline{\text { Rukmiyati dkk., 2016); (Afandi, 2017); (Hanadia, 2017); (Oliveira }}$ dkk., 2017); (Prabadewi dkk., 2019) membuktikan bahwa kualitas sistem mempengaruhi Kepuasan Pengguna.

Kualitas informasi mengacu pada kualitas output dari sistem informasi yang dapat diukur dari sisi keakuratan, presisi, reliabilitas, kelengkapan, relevan, tepat waktu, dan dapat dimengerti (Chinomona et al., 2014). Mengacu dari penelitian sebelumnya yang

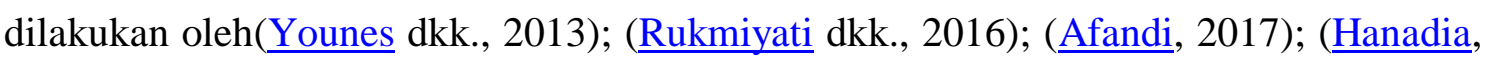
2017); (Oliveira dkk., 2017) membuktikan bahwa kepuasan pengguna tidak hanya dipengaruhi oleh Kualitas Sistem tetapi Kualitas Informasi juga mempengaruhi kepuasan pengguna.

Penelitian yang dilakukan oleh (Davis, 1989) menyatakan bahwa Persepsi Manfaat (perceived usefulness) merupakan proses pengukuran yang menyatakan tingkat kepercayaan seseorang dalam menggunakan suatu sistem dapat meningkatkan kinerja seseorang. Penelitian lain yang dilakukan oleh (Seddon, 1997) dengan memodifikasi model kesuksesan sistem informasi DeLone dan McLean membuktikan bahwa Persepsi 
Analisis Pengaruh Kualitas Sistem Informasi, Kualitas Informasi dan Perceived Usefulness Terhadap Kepuasan Pengguna Aplikasi Olibsifrs (Psak) 71 (Studi pada Bank

Papua)

Manfaat (perceived usefulness) berpengaruh terhadap Kepuasan Pengguna sistem informasi. Kedua hal ini dibuktikan melalui penelitian yang dilakukan oleh (Rukmiyati dkk., 2016); (Hanadia, 2017) bahwa Persepsi Manfaat (perceived usefulness) berpengaruh terhadap kepuasan pengguna.

Kepuasan pengguna didefinisikan sebagai evaluasi keseluruhan dari pengalaman yang dirasakan oleh pengguna sistem dan dampak potensial dalam menggunakan sistem informasi (Rahmawati dkk., 2015).

Berdasarkan uraian diatas dan latar belakang yang dijelaskan, maka peneliti tertarik untuk melakukan penelitian yang berjudul "Analisis Pengaruh Kualitas Sistem Informasi, Kualitas Informasi Dan Perceived usefulness Terhadap Kepuasan Pengguna Aplikasi OlibsIFRS (PSAK) 71 (Studi Pada Bank Papua)”.

Menurut hasil penelitian (Fendini, 2013), menunjukkan Secara parsial dan simultan variabel Kualitas Sistem dan Kualitas Informasi berpengaruh terhadap Kepuasan Pengguna sistem informasi akuntansi pada PT. Indomarco Prismatama Cabang Banjarmasin.Menurut hasil penelitian (Sumiyati dkk., 2013), menunjukkan bahwa Kualitas Sistem memiliki pengaruh yang signifikan terhadap Kepuasan Pengguna sistem informasi akuntansi, sedangkan Kualitas Informasi dan perceived usefulness tidak memiliki pengaruh yang signifikan terhadap Kepuasan Pengguna sistem informasi akuntansi.

Hasil penelitian (Soekamto dkk., 2021) menunjukkan bahwa secara parsial sistem informasi akuntansi dan perceived usefulness berpengaruh terhadap Kepuasan Pengguna, begitu pula secara simultan sistem informasi akuntansi dan perceived usefulness juga berpengaruh terhadap Kepuasan Pengguna.Hasil penelitian (Soekamto, 2021) menunjukkan bahwa Kualitas Sistem informasi telah terbukti mempengaruhi Kepuasan Pengguna akhir perangkat lunak analisis kredit di PT. Bank Rakyat Indonesia, Tbk. Cabang Bengkulu. Ini berarti bahwa aplikasi LAS dapat meningkatkan kapasitas pemrosesan data, memiliki sistem keamanan yang tinggi, memiliki fasilitas koreksi data yang baik. Kualitas Informasi telah terbukti mempengaruhi kepuasan pengguna akhir perangkat lunak analisis kredit di PT. Bank Rakyat Indonesia, Tbk. Cabang Bengkulu, artinya software LAS dapat meningkatkan kepuasan pengguna karena analisis kredit yang dilakukan dapat menghasilkan data yang akurat, andal, tepat waktu dan relevan. Dan hasil terakhir dirasakan kegunaannya terbukti mempengaruhi Kepuasan Pengguna akhir perangkat lunak analisis kredit di PT. Bank Rakyat Indonesia, Tbk. Cabang Bengkulu, artinya aplikasi LAS sangat membantu dalam menyelesaikan analisis dengan cepat, aplikasi LAS mampu meningkatkan efektivitas kerja dan aplikasi LAS memudahkan karyawan untuk menyelesaikan pekerjaan sehingga dapat meningkatkan kepuasan pengguna.

Hasil penelitian (Haqiqi dkk., 2019) menunjukkan bahwa variabel Kualitas Sistem, Kualitas Informasi, dan perceived usefulness berpengaruh terhadap kepuasan pengguna akhir software akuntansi.Hasil penelitian (Buana dkk., 2018) menunjukkan bahwa Kualitas Sistem akuntansi, Kualitas Informasi dan Perceived Usefullness berpengaruh positif dan signifikan pada Kepuasan Pengguna Sistem Informasi Akuntansi. 
Koefisien determinasi (R2) sebesar 0,554 hal ini berarti 55,4 persen kepuasan pengguna Informasi Akuntansi pada PDAM Tirta Mangutama Kabupaten Badung dipengaruhi oleh variabel-variabel Kualitas Sistem Informasi Akuntansi, Kualitas Informasi, dan perceived usefulness, sebaliknya 44,6 persen dipengaruhi oleh variabel-variabel lain yang tidak diteliti.

Hasil penelitian (Pratomo, 2016) menunjukkan bahwa (1) Kualitas Sistem informasi berpengaruh signifikan terhadap kepuasan pengguna sistem informasi akuntansi. (2) Kualitas Informasi tidak berpengaruh signifikan terhadap kepuasan pengguna sistem informasi akuntansi. (3) perceived usefulness tidak berpengaruh signifikan terhadap kepuasan pengguna sistem informasi akuntansi. (4) Kualitas Sistem, Kualitas Informasi, dan perceived usefulness berpengaruh signifikan terhadap Kepuasan Pengguna sistem informasi akuntansi. Hasil penelitian (Rukmiyati dkk., 2016) menunjukkan bahwa adanya pengaruh yang siginifikan positif pada variabel Kualitas Sistem, Kualitas Informasi dan perceived usefulness terhadap Kepuasan Pengguna sistem informasi.

Hasil penelitian (Kartika dkk., 2016) menunjukkan bahwa Kualitas Sistem berpengaruh terhadap perceived usefulness, Kualitas Informasi berpengaruh terhadap Perceived usefulness, Kualitas Sistem informasi berpengaruh terhadap Kepuasan Pengguna, Kualitas Informasi tidak berpengaruh terhadap Kepuasan Pengguna dan perceived usefulness berpengaruh terhadap Kepuasan Pengguna.Hasil penelitian (Marlina, 2016) menunjukkan bahwa (1) Kualitas Sistem informasi akuntansi, kualitas informasi akuntansi dan kepuasan pengguna termasuk dalam kategori baik, meskipun belum mencapai kondisi yang ideal; (2) Kualitas Sistem informasi akuntansi berpengaruh signifikan terhadap Kepuasan Pengguna (3) Kualitas Informasi akuntansi berpengaruh signifikan terhadap Kepuasan Pengguna.

Penelitian ini diharapkan dapat memberikan kontribusi terhadap penelitian terkait pengukuran kesuksesan Sistem Informasi khususnya Kualitas Sistem Informasi, Kualitas Informasi Dan perceived usefulness terhadap Kepuasan Pengguna serta dapat menjadi jalan pembuka penelitian-penelitian berikutnya.

Sistem informasi adalah sebuah rangkaian prosedur formal dimana data dikumpulkan, diproses menjadi informasi, dan didistribusikan kepada para pemakai (Hall, 2001). Sistem Informasi merupakan sistem dalam suatu organisasi yang mendukung fungsi operasi organisasi dalam mengolah transaksi harian menjadi laporanlaporan yang dibutuhkan dan bersifat manajerial (Amalia Pratomo, 2016). Sistem Informasi merupakan kumpulan dari sub sistem yang terdiri secara fisik dan non fisik yang saling berhubungan satu sama lain untuk mengolah data menjadi informasi yang dibutuhkan oleh pengguna sistem. Sistem mempunyai 3 (tiga) fungsi dasar yang meliputi:

a. Masukan (input)

b. Pemprosesan (processing)

c. Keluaran (output)

Menurut DeLone dan McLean (DeLone \& McLean, 2003) Kualitas Sistem merupakan performa sistem informasi yang terdiri dari perangkat keras, perangkat lunak, 
Analisis Pengaruh Kualitas Sistem Informasi, Kualitas Informasi dan Perceived Usefulness Terhadap Kepuasan Pengguna Aplikasi Olibsifrs (Psak) 71 (Studi pada Bank

Papua)

dan prosedur-prosedur yang menghasilkan informasi yang dibutuhkan oleh pengguna sistem. Kualitas Sistem dapat diukur dari sisi response time, system reliability, ease to use, system flexibility, dan system security. Hal ini memperlihatkan bahwa jika pemakai sistem informasi merasa bahwa menggunakan sistem tersebut mudah, andal dan canggih mereka tidak memerlukan upaya banyak untuk menggunakannya, sehingga mereka akan lebih banyak waktu untuk mengerjakan hal lain yang kemungkinan akan meningkatkan kinerja mereka secara keseluruhan (Rukmiyati dkk., 2016).

Kualitas sistem merupakan proses untuk mengukur sistem informasi yang difokuskan pada hasil interaksi antara pengguna dan sistem (Pawirosumarto, 2016). Kualitas sistem informasi yang digunakan dalam perusahaan, berkaitan dengan sistem informasi yang diterapkan sesuai dengan kebutuhan dan kemampuan pemakai sehingga dapat digunakan untuk mengolah data menjadi suatu informasi yang berkualitas dan berguna bagi pemakai informasi tersebut (Amalia dkk., 2016).

Dari penjabaran diatas, dapat disimpulkan bahwa kualitas sistem merupakan salah satu bagian dari pengukuran dalam menentukan kesuksesan Sistem Informasi yang dapat menyediakan informasi yang berguna sesuai dengan yang dibutuhkan oleh pengguna.

\section{Metode Penelitian}

Metode penelitian didefinisikan sebagai cara atau proses yang digunakan untuk mendapatkan suatu data dalam suatu penelitian ilmiah. Metode penelitian yang digunakan dalam penelitian ini yaitu metode penelitian kuantitatif. Metode penelitian kuantitatif berlandaskan pada filsafat positivisme yang bertujuan untuk meneliti pada suatu populasi atau sampel tertentu. Metode kuantitatif ini menganalisis data penelitian menggunakan statistic (Sugiyono, 2012).

Dalam penelitian sampel yang digunakan adalah teknik Purposive Sampling. Menurut Sugiyono, Purposive sampling yaitu penentuan sampel dengan kriteria tertentu. Kriteria sampel dalam penelitian ini adalah pengguna aplikasi OlibsIFRS (PSAK) 71 sebanyak 52 orang.

Langkah-langkah penelitian ini meliputi analisis masalah yang dihadapi, perencanaan model, variabel, populasi dan sampel, indikator variabel serta teknik dan metode pengumpulan dan pengolahan data. Langkah-langkah dalam penelitian ini digambarkan sebagai berikut :

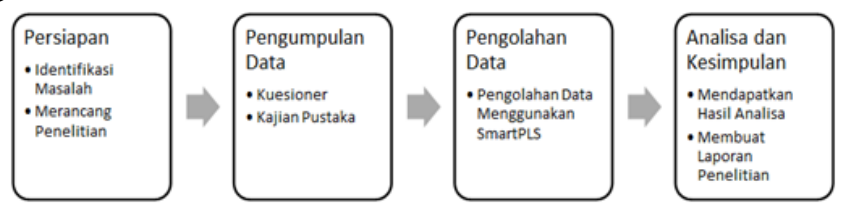

Gambar5 Langkah-langkah Penelitian (Arikunto, 2009)

Berdasarkan gambar diatas, langkah-langkah penelitian dapat dijabarkan sebagai berikut

1. Persiapan

2. Pengumpulan Data

3. Pengolahan Data 
4. Analisa dan Kesimpulan

Sampel menurut (Arikunto, 2009) merupakan bagian dari populasi yang diteliti. Penelitian ini menggunakan metode convenience sampling dalam menentukan pengambilan jumlah sampel. Metode convenience sampling didefinisikan oleh Sekaran (Sekaran, 2011) yaitu merupakan teknik yang mengumpulkan informasi dari anggota populasi yang dengan sukarela bersedia memberikannya (Sekaran, 2011).

Alat analisis yang digunakan dalam mengolah data untuk menguji hipotesis yang diajukan adalah dengan menggunakan analisis Partial Least Square (PLS)-Structural Equation Modeling (SEM). PLS SEM tidak mengharuskan peneliti menggunakan jumlah data yang besar. Dengan demikian, prosedur ini memberikan keuntungan bagi pengguna saat kesulitan mencari data dalam jumlah yang besar.

Software yang digunakan untuk melakukan analisis data adalah SmartPLS 3.29. Tahapan analisis data dengan model pengukuran reflektif dengan SmartPLS adalah sebagai berikut (Haryono, 2016):

1. Membuat diagram jalur sesuai dengan teori. Digunakan untuk memodelkan variabel laten Kualitas Sistem Informasi $\left(\mathrm{X}_{1}\right)$, Kualitas Informasi $\left(\mathrm{X}_{2}\right)$, Perceived usefulness $\left(\mathrm{X}_{3}\right)$ dan Kepuasan Pengguna $(\mathrm{Y})$ beserta indikatorindikatornya.

2. Menyiapkan data di excel (.csv) untuk diolah dalam aplikasi SmartPLS. Data berasal dari hasil pengisian kuesioner yang disebar kepada para responden sesuai dengan kriteria sampel.

3. Mengambar diagram jalur di SmartPLS

4. Menghitung nilai parameter-parameter di SmartPLS:

a. Menguji validitas data dengan melakukan pengujian convergent validity. Nilai pada pengukuran ini didasarkan pada hubungan antara construct score dengan itemscore/componentscore. Ukuran reflektif dikatakan tinggi jika berkorelasi lebih dari 0,70 . Tetapi, nilai loading 0,50 hingga 0,60 sudah dianggap cukup untuk pengembangan penelitian pada tahap awal (Anuraga et al., 2017).

b. Menguji validitas data dengan melakukan pengujian discriminant validity. Nilai ini merupakan nilai cross loading antara konstruk dengan indikatornya untuk mengetahui konstruk yang diskriminan. Untuk menilai discriminant validity dilakukan dengan membandingkan korelasi nilai average variance extracted (AVE) pada setiap konstruknya. Nilai discriminant validity yang baik apabila memiliki nilai square root of average variance extracted (AVE) yang lebih besar dari 0,50 (Anuraga et al., 2017).

c. Pengujian Reliabilitas Konstruk. Evaluasi terhadap nilai reliabilitas konstruk diukur dengan nilai Cronbach's Alpha dan Composite Reliability. Nilai Cronbach's Alpha $\geq 0,6$ dan Composite Reliability harus $\geq 0,7$. 
Analisis Pengaruh Kualitas Sistem Informasi, Kualitas Informasi dan Perceived Usefulness Terhadap Kepuasan Pengguna Aplikasi Olibsifrs (Psak) 71 (Studi pada Bank

Papua)

d. Melakukan Evaluasi Inner Model. Dianalisis dengan melihat signifikansi hubungan antar konstruk yang ditunjukkan oleh nilai $t$-statistic. Dimana indikator yang memiliki nilai $t$-statistic $\geq 1,68$ dikatakan valid.

e. Pengujian hipotesis didasarkan hasil dari path coefficients untuk melihat hubungan antar variabel.

\section{Hasil dan Pembahasan}

Pada penelitian ini terdapat empat variabel yaitu Kualitas Sistem Informasi, Kualitas Informasi, Perceived usefulness dan Kepuasan Pengguna. Indikator dari masingmasing variabel dapat dilihat pada Tabel 1 .

Tabel1: Tabel Indikator Pengukuran Variabel Penelitian

\begin{tabular}{|c|c|c|}
\hline Variabel & Indikator & Ref \\
\hline Kualitas & 1. Kemudahan menggunakan $\left(\mathrm{X}_{1.1}\right)$ & (Fendini \\
\hline \multirow{5}{*}{$\begin{array}{l}\text { Sistem } \\
\left(\mathrm{X}_{1}\right)\end{array}$} & 2. Kecepatan akses $\left(\mathrm{X}_{1.2}\right)$ & dkk., \\
\hline & 3. Keandalan sistem $\left(\mathrm{X}_{1.3}\right)$ & 2014;Utomo \\
\hline & 4. Fleksibilitas sistem $\left(\mathrm{X}_{1.4}\right)$ & $\mathrm{dkk}, 2017)$ \\
\hline & 5. Keamanan sistem $\left(\mathrm{X}_{1.5}\right)$ & \\
\hline & 6. Integrasi system $\left(\mathrm{X}_{1.6}\right)$ & \\
\hline Kualitas & 1. Keakuratan informasi $\left(\mathrm{X}_{2.1}\right)$ & (DeLone dan \\
\hline Informas & 2. Ketepatan waktu $\left(\mathrm{X}_{2.2}\right)$ & McLean, \\
\hline $\mathrm{i}$ & 3. Kelengkapan informasi $\left(\mathrm{X}_{2.3}\right)$ & 1992; Utomo \\
\hline \multirow[t]{2}{*}{$\left(\mathrm{X}_{2}\right)$} & 4. Relevansi $\left(\mathrm{X}_{2.4}\right)$ & dkk., 2017) \\
\hline & 5. Penyajian informasi $\left(X_{2.5}\right)$ & \\
\hline Perceive & 1. Meningkatkan produktivitas $\left(\mathrm{X}_{3.1}\right)$ & (Davis, 1989; \\
\hline & 2. Efektif $\left(\mathrm{X}_{3.2}\right)$ & Hanadia \\
\hline usefulnes & 3. Mempercepat pekerjaan $\left(X_{3.3}\right)$ & dkk.,2017) \\
\hline$s$ & 4. Bermanfaat $\left(\mathrm{X}_{3.4}\right)$ & \\
\hline \multirow[t]{2}{*}{$\left(\mathrm{X}_{3}\right)$} & 5. Mempermudah pekerjaan $\left(X_{3.5}\right)$ & \\
\hline & 6. Meningkatkan kinerja $\left(\mathrm{X}_{3.6}\right)$ & \\
\hline Kepuasa & 1. Efisiensi $\left(\mathrm{Y}_{.1}\right)$ & (DeLone dan \\
\hline $\mathrm{n}$ & 2. Efektivitas (Y.2) & McLean, \\
\hline Penggun & 3. Kepuasan informasi (Y.3) & 1992; \\
\hline \multirow{3}{*}{$\begin{array}{c}\mathrm{a} \\
(\mathrm{Y})\end{array}$} & 4. Kepuasan pengguna & Seddon dan \\
\hline & antarmuka $(\mathrm{Y} .4)$ & Kiew, 1997; \\
\hline & 5. Kepuasan menyeluruh (Y.5) & $\begin{array}{l}\text { Sultono dkk, } \\
\text { 2015) }\end{array}$ \\
\hline
\end{tabular}

Dengan menggunakan SmartPLS 3.29 dilakukan pemodelan variabel Kualitas Sistem Informasi, Kualitas Informasi, Perceived usefulness dan Kepuasan Pengguna beserta indikator-indikatornya. Penelitian ini menggunakan metode analisis model 
reflektif yaitu tanda panah berawal dari variabel laten menuju indikatornya seperti telihat pada Gambar 6.

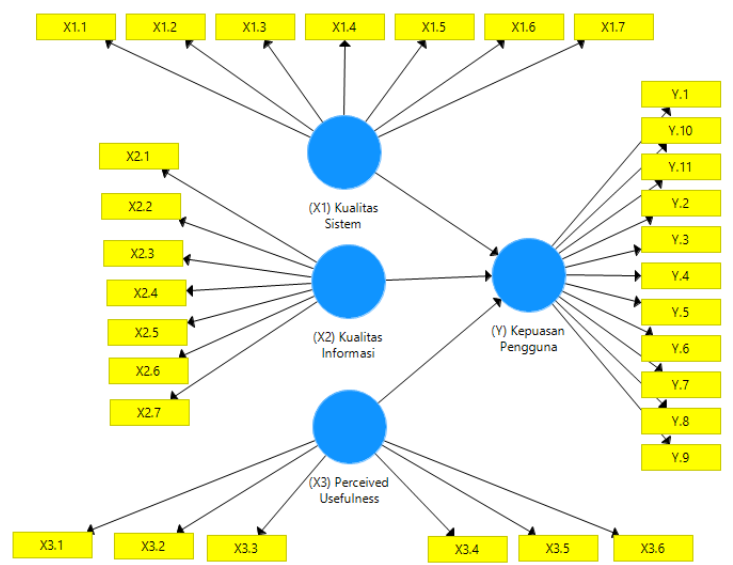

Pengujian data dengan menggunakan PLS-SEM dilakukan melalui dua tahap (Hussein, 2015), yaitu Evaluasi Outer Model dan Evaluasi Inner Model. Evaluasi Outer Model terdiri dari uji validitas dan uji reliabilitas. Uji validitas terdiri dari pengujian Convergent Validity (loading factor dan AVE) dan discriminant validity (fornell-larcker criteria dan cross loading). Uji reliabilitas terdiri dari pengujian Cronbach's Alpha dan Composite Reliability. Evaluasi Inner Model terdiri dari pengujian t-statistic dan rsquare.

Evaluasi hubungan antara variabel dengan indikatornya terdiri dari evaluasi terhadap convergent validity, discriminant validity, composite reliability dan cronbach's alpha. Convergent validity dapat dievaluasi dengan melihat nilai average variance extracted (AVE). Indikator validitas dapat dilihat juga dari nilai loading factor. Bila nilai loading factor suatu indikator lebih dari 0,5 maka dapat dikatakan valid. Sebaliknya, bila nilai loading factor kurang dari 0,5 maka dikeluarkan dari model. Discriminant validity dalam bentuk square root of average variance extracted (AVE) dan Composite reliability dan cronbach's alpha digunakan untuk mengevaluasi reliabilitas suatu indikator. Berikut adalah model pengukuran dengan menggunakan SmartPLS:

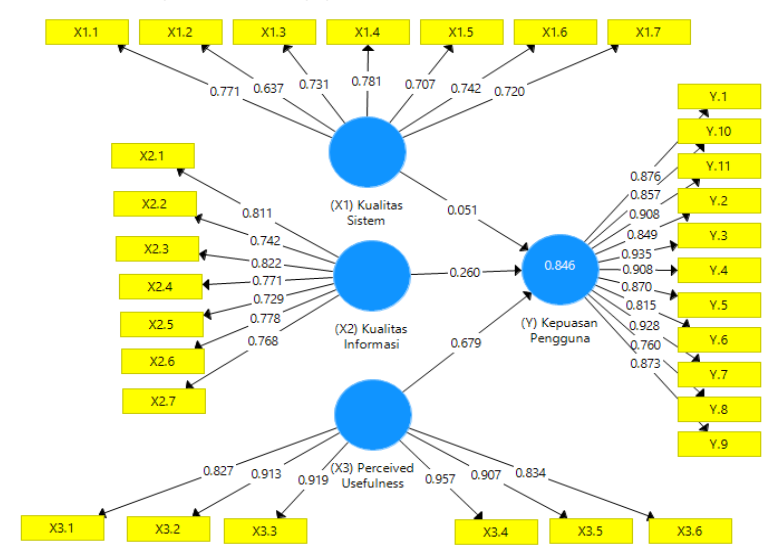

\section{A. Pengujian Convergent Validity}

Gambar 7: Output Model Pengukuran

Convergent Validity merupakan pengujian yang dilakukan untuk melihat validitas setiap indikator dengan melihat nilai average variance extracted (AVE) masing-masing 
variabel dimana nilainya harus lebih besar dari 0,5 sehingga dapat dikatakan memiliki nilai convergent validity yang baik.

Tabel 2: Average Variance Extracted (AVE)

\begin{tabular}{|c|c|c|}
\hline Variabel & $\begin{array}{l}\text { Nilai } \\
\text { AVE }\end{array}$ & Keterangan \\
\hline Kualitas Sistem $\left(\mathrm{X}_{1}\right)$ & 0,531 & Valid \\
\hline Kualitas Informasi $\left(\mathrm{X}_{2}\right)$ & 0,60 & Valid \\
\hline Perceived usefulness $\left(\mathrm{X}_{3}\right)$ & 0,80 & Valid \\
\hline Kepuasan Pengguna (Y) & 0,76 & Valid \\
\hline
\end{tabular}

Tabel 2 menjelaskan nilai dari AVE dari variabel Kualitas Sistem, Kualitas Informasi, Perceived usefulness dan Kepuasan Pengguna yang dapat dilihat bahwa setiap variabel tersebut memiliki nilai AVE diatas 0,5. Nilai AVE terendah dihasilkan oleh variabel Kualitas Sistem yaitu sebesar $\mathbf{0 , 5 3 1}$. Hal ini menunjukkan bahwa setiap variabel tersebut memiliki nilai validitas yang baik dari setiap indikator kuesioner yang digunakan untuk mengetahui pengaruh dari setiap variabel tersebut.

\section{B. Pengujian Discriminant Validity}

Untuk melihat validitas dari konstruk, dapat diketahui dengan cara membandingkan nilai AVE setiap konstruk dengan korelasi konstruk lainnya. Model mempunyai discriminant validity yang baik jika akar AVE untuk setiap konstruk lebih besar daripada korelasi antara konstruk dan konstruk lainnya. Tabel 3 dibawah ini menunjukkan hasil output korelasi antar konstruk.

Tabel 3: Fornell Larcker Criteria

\begin{tabular}{ccccc}
\hline Variabel & $\begin{array}{c}\text { Kualitas } \\
\text { Sistem } \\
\left(\mathbf{X}_{\mathbf{1}}\right)\end{array}$ & $\begin{array}{c}\text { Kualitas } \\
\text { Informasi } \\
\left(\mathbf{X}_{\mathbf{2}}\right)\end{array}$ & $\begin{array}{c}\text { Perceived } \\
\text { usefulness } \\
\left(\mathbf{X}_{\mathbf{3}}\right)\end{array}$ & $\begin{array}{c}\text { Kepuasan } \\
\text { Pengguna }(\mathbf{Y})\end{array}$ \\
\hline $\begin{array}{c}\text { Kualitas } \\
\text { Sistem }\left(\mathrm{X}_{1}\right)\end{array}$ & $\mathbf{0 , 7 2 8 *}$ & & \\
\hline $\begin{array}{c}\text { Kualitas } \\
\text { Informasi }\left(\mathrm{X}_{2}\right)\end{array}$ & 0,275 & $\mathbf{0 , 7 7 5 *}$ & \\
\hline $\begin{array}{c}\text { Perceived } \\
\text { usefulness } \\
\left(\mathrm{X}_{3}\right)\end{array}$ & 0,397 & $\mathbf{0 , 7 9 3}$ & $0,894^{*}$ & \\
\hline $\begin{array}{c}\text { Kepuasan } \\
\text { Pengguna (Y) }\end{array}$ & 0,391 & $\mathbf{0 , 8 1 2}$ & 0,605 & $0,872^{*}$ \\
\hline
\end{tabular}

Sumber: Data kuesioner yang diolah (2021) 
Tabel4: Akar Average Variance Extracted (AVE)

\begin{tabular}{ccc} 
Variabel & Nilai $\boldsymbol{A} \boldsymbol{V E}$ & $\begin{array}{c}\text { Nilai } \\
\text { Akar } \\
\boldsymbol{A} \boldsymbol{V E}\end{array}$ \\
\hline Kualitas Sistem $\left(\mathrm{X}_{1}\right)$ & 0,531 & 0,728 \\
\hline Kualitas Informasi $\left(\mathrm{X}_{2}\right)$ & 0,60 & 0,775 \\
\hline $\begin{array}{c}\text { Perceived usefulness } \\
\left(\mathrm{X}_{3}\right)\end{array}$ & 0,80 & 0,894 \\
\hline Kepuasan Pengguna (Y) & 0,76 & 0,872 \\
\hline \multicolumn{2}{l}{ Sumber: Data kuesioner yang diolah $(2021)$}
\end{tabular}

*Akar AVE, perhitungan dijelaskan pada tabel 4

Dari tabel diatas dapat disimpulkan bahwa akar AVE pada seluruh konstruk lebih tinggi daripada korelasi antar variabel. Sebagai contoh pada Perceived usefulness $\left(\mathrm{X}_{3}\right)$ memiliki akar AVE 0,894 lebih besar daripada korelasi antara Perceived usefulness $\left(\mathrm{X}_{3}\right)$ dengan Kualitas Informasi $\left(\mathrm{X}_{2}\right)$ sebesar $\mathbf{0 , 7 9 3}$, Perceived usefulness $\left(\mathrm{X}_{3}\right)$ dengan Kualitas Sistem $\left(\mathrm{X}_{1}\right)$ sebesar $\mathbf{0 , 3 9 7}$. Begitu juga dengan nilai akar AVE untuk variabel yang lain seluruhnya lebih besar dari koefisien korelasi antar variabel.

Dengan demikian konstruk variabel Kualitas Sistem $\left(\mathrm{X}_{1}\right)$, Kualitas Informasi $\left(\mathrm{X}_{2}\right)$, Perceived usefulness $\left(\mathrm{X}_{3}\right)$, Kepuasan Pengguna $(\mathrm{Y})$ dapat dinyatakan valid karena akar AVE > koefisien korelasinya, artinya seluruh variabel ini telah memiliki discriminant validity yang tinggi.

\section{Pengujian Cronbach's Alpha dan Composite Reliability}

Composite Reliability dan Cronbach's Alpha merupakan pengujian yang dilakukan untuk melihat reliabilitas dari setiap indikator variabel. Suatu data dikatakan reliabel jika nilai composite reliability lebih dari 0,7 dan jika nilai cronbach's alpha yang dihasilkan lebih dari 0,6.

Tabel 5: Composite Reliability dan Cronbach's Alpha

\begin{tabular}{cccc}
\hline Variabel & $\begin{array}{c}\text { Nilai } \\
\text { Composite } \\
\text { Reliability }\end{array}$ & $\begin{array}{c}\text { Nilai } \\
\text { Cronbach's }\end{array}$ & Keterangan \\
& 0,887 & 0,857 & Reliabel \\
\hline Kualitas Sistem $\left(\mathrm{X}_{1}\right)$ & 0,913 & 0,889 & Reliabel \\
\hline Kualitas Informasi $\left(\mathrm{X}_{2}\right)$ & 0,96 & Reliabel \\
\hline Perceived usefulness $\left(\mathrm{X}_{3}\right)$ & 0,96 & 0,949 & Reliabel \\
\hline Kepuasan Pengguna $(\mathrm{Y})$ & 0,972 & 0,968 &
\end{tabular}

Dari tabel 5 dapat dilihat setiap variabel tersebut memiliki nilai composite reliability diatas 0,7 dan nilai cronbach's alpha diatas 0,6. Hal ini menunjukan bahwa internal consistency dari variabel dependen (Kualitas Sistem, Kualitas Informasi, dan Perceived usefulness) serta variabel independen (Kepuasan Pengguna) memiliki nilai reliabilitas yang baik. 
Analisis Pengaruh Kualitas Sistem Informasi, Kualitas Informasi dan Perceived Usefulness Terhadap Kepuasan Pengguna Aplikasi Olibsifrs (Psak) 71 (Studi pada Bank

Papua)

\section{Pengujian Hipotesis}

Pengujian hipotesis berdasarkan pada nilai signifikansi dalam pengujian model struktural yang dapat dilihat dari nilai t-statistic antara variabel independen dengan variabel dependen dalam tabel Path Coefficient. Untuk pengujian hipotesis dalam penelitian ini menggunakan nilai alpha $(\alpha) 5 \%$ yaitu 1,68 . Sehingga kriteria penerimaan atau penolakan hipotesis adalah $\mathrm{H} 1$ diterima dan $\mathrm{H} 0$ ditolak ketika nilai t-statistic > 1,68. Hasil pengolahan data menggunakan SmartPLS dapat dilihat pada tabel dibawah ini :

Tabel 6: Path Coefficients

\begin{tabular}{ccc}
\hline Path & $\begin{array}{c}\text { Original } \\
\text { Sample }\end{array}$ & T Statistics \\
\hline $\begin{array}{c}\text { Kualitas Sistem } \rightarrow \\
\text { Kepuasan Pengguna }\end{array}$ & $\mathbf{0 , 0 5 1}$ & $\mathbf{0 , 8 5 9}$ \\
\hline $\begin{array}{c}\text { Kualitas Informasi } \rightarrow \\
\text { Kepuasan Pengguna }\end{array}$ & $\mathbf{0 , 2 6 0}$ & $\mathbf{2 , 4 7 8}$ \\
\hline $\begin{array}{c}\text { Perceived usefulness } \\
\rightarrow \text { Kepuasan } \\
\text { Pengguna }\end{array}$ & $\mathbf{0 , 6 7 9}$ & $\mathbf{5 , 7 3 9}$ \\
\hline
\end{tabular}

Sumber: Data kuesioner yang diolah (2021)

Tabel 7: R-square

\begin{tabular}{cc|}
\hline Variabel & $\begin{array}{c}\text { Nilai } \\
\boldsymbol{R} \text {-square }\end{array}$ \\
\hline $\begin{array}{c}\text { Kepuasan Pengguna } \\
\text { (Y) }\end{array}$ & $\mathbf{0 , 8 4 6}$ \\
\hline
\end{tabular}

Sumber: Data kuesioner yang diolah (2021)

Dari tabel 6 di atas dapat dilihat nilai original sample Kualitas Sistem adalah sebesar $\mathbf{0 , 0 5 1}$ dengan signifikansi dibawah 5\% yang ditunjukkan dengan nilai t-statistic 0,859 lebih kecil dari nilai t-tabel sebesar 1,68. Nilai original sample positif mengindikasikan bahwa Kualitas Sistem berpengaruh positif terhadap Kepuasan Pengguna. Berdasarkan hasil regresi tersebut dapat disimpulkan bahwa hipotesis pertama ditolak

Dari tabel 6 di atas dapat dilihat nilai original sample Kualitas Informasi adalah sebesar 0,260 dengan signifikansi dibawah 5\% yang ditunjukkan dengan nilai t-statistic 2,478 lebih besar dari nilai t-tabel sebesar 1,68. Nilai original sample positif mengindikasikan bahwa Kualitas Informasi berpengaruh positif terhadap Kepuasan Pengguna. Berdasarkan hasil regresi tersebut dapat disimpulkan bahwa hipotesis kedua diterima.

Dari tabel 6 di atas dapat dilihat nilai original sample Perceived usefulness adalah sebesar 0,679 dengan signifikansi dibawah 5\% yang ditunjukkan dengan nilai t-statistic 5,739 lebih besar dari nilai t-tabel sebesar 1.68. Nilai original sample positif mengindikasikan bahwa Perceived usefulness berpengaruh positif terhadap Kepuasan 
Pengguna. Berdasarkan hasil regresi tersebut dapat disimpulkan bahwa hipotesis ketiga diterima.

Dari tabel 7 dapat dilihat R-square dengan nilai 0,846, ini menunjukkan bahwa untuk variabel Kualitas Sistem, Kualitas Informasi dan Perceived usefulness dari setiap indikator masing-masing variabel secara bersama-sama memberikan pengaruh korelasi yang kuat/signifikan terhadap variabel Kepuasan Pengguna (Y) sebesar 84,6\%, menurut Chin (Chin, 1998), apabila nilai R-square sebesar 0,67 maka dinyatakan kuat/signifikan, nilai 0,33 dinyatakan moderat dan nilai 0,19 dinyatakan lemah sedangkan sisanya sebesar $\mathbf{1 5 , 4 \%}$ dijelaskan oleh variabel dan indikator lain yang tidak dimasukan dalam model penelitian. Berdasarkan hasil regresi tersebut dapat disimpulkan bahwa hipotesis keempat diterima.

\section{Pembahasan}

Berdasarkan dari hasil pengujian hipotesis yang pertama dapat disimpulkan bahwa variabel Kualitas Sistem tidak berpengaruh terhadap Kepuasan Pengguna. Hal ini menandakan secara langsung bahwa tidak terdapat pengaruh signifikan antara Kualitas Sistem terhadap Kepuasan Pengguna karena memiliki t-statistic sebesar 0,859 lebih kecil dari t-tabel $(1,68)$. Namun, karena Kualitas Sistem masih terdapat korelasi sebesar 84,6\% terhadap kepuasan pengguna maka ada baiknya untuk tetap memperhatikan variabel Kualitas Sistem tersebut. Hasil penelitian ini berbanding terbalik dengan penelitian sebelumnya yang dilakukan oleh (Amalia dan Pratomo, 2016); (ukmiyati \& Budiartha, 2016); (Sumiyati et al., 2013); (Fendini, 2013) yang membuktikan bahwa Kualitas Sistem berpengaruh terhadap Kepuasan Pengguna, tetapi hasil penelitian ini mendukung hasil penelitian sebelumnya yang dilakukan oleh (Hanadia, 2017) yang membuktikan bahwa Kualitas Sistem tidak berpengaruh terhadap Kepuasan Pengguna.

Berdasarkan dari hasil pengujian hipotesis yang kedua dapat disimpulkan bahwa variabel Kualitas Informasi berpengaruh terhadap Kepuasan Pengguna. Hal ini menandakan secara langsung bahwa terdapat pengaruh signifikan antara Kualitas Informasi terhadap Kepuasan Pengguna karena memiliki t-statistic sebesar 2,478 lebih besar dari t-tabel $(1,68)$. Hasil penelitian ini berbanding terbalik dengan penelitian sebelumnya yang dilakukan oleh (Amalia dkk., 2016); (Kartika dkk., 2016); (Sumiyati et al., 2013)yang membuktikan bahwa Kualitas Informasi tidak berpengaruh terhadap Kepuasan Pengguna, tetapi hasil penelitian ini mendukung hasil penelitian sebelumnya yang dilakukan oleh (Rukmiyati dkk., 2016); (Soekamto dkk., 2021); (Fendini, 2013) yang membuktikan bahwa Kualitas Informasi berpengaruh terhadap Kepuasan Pengguna.

Berdasarkan dari hasil pengujian hipotesis yang ketiga dapat disimpulkan bahwa variabel Perceived usefulness berpengaruh terhadap Kepuasan Pengguna. Hal ini menandakan secara langsung bahwa terdapat pengaruh signifikan antara Perceived usefulness terhadap Kepuasan Pengguna karena memiliki t-statistic sebesar 5,739 lebih besar dari t-tabel $(1,68)$. Hasil penelitian ini berbanding terbalik dengan penelitian sebelumnya yang dilakukan oleh (Amalia dkk., 2016); (Sumiyati et al., 2013) yang membuktikan bahwa Perceived usefulness tidak berpengaruh terhadap Kepuasan 
Analisis Pengaruh Kualitas Sistem Informasi, Kualitas Informasi dan Perceived Usefulness Terhadap Kepuasan Pengguna Aplikasi Olibsifrs (Psak) 71 (Studi pada Bank

Papua)

Pengguna, tetapi hasil penelitian ini mendukung hasil penelitian sebelumnya yang dilakukan oleh (Rukmiyati dkk., 2016); (Buana dkk., 2018); (Soekamto dkk., 2021) yang membuktikan bahwa Perceived usefulness berpengaruh terhadap Kepuasan Pengguna.

Berdasarkan dari hasil pengujian hipotesis yang keempat dengan nilai R-square sebesar 0,846 dapat disimpulkan bahwa variabel Kualitas Sistem, Kualitas Informasi dan Perceived usefulness secara bersama-sama (simultan) berpengaruh terhadap Kepuasan Pengguna. Hasil penelitian ini mendukung hasil penelitian sebelumnya yang dilakukan

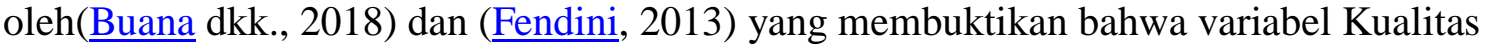
Sistem, Kualitas Informasi dan Perceived usefulness secara bersama-sama (simultan) berpengaruh terhadap Kepuasan Pengguna.

\section{Kesimpulan}

Penelitian ini bertujuan untuk menganalisa Pengaruh Kualitas Sistem, Kualitas Informasi dan Perceived usefulness terhadap Kepuasan Pengguna Aplikasi OlibsIFRS (PSAK) 71 (Studi Kasus PT. Bank Papua). Dalam penelitian ini, variabel independen yang digunakan yaitu Kualitas Sistem $\left(\mathrm{X}_{1}\right)$, Kualitas Informasi $\left(\mathrm{X}_{2}\right)$ dan Perceived usefulness $\left(\mathrm{X}_{3}\right)$, sedangkan untuk variabel dependennya yaitu Kepuasan Pengguna (Y). Penelitian ini diolah menggunakan metode Partial Least Square (PLS) dengan bantuan software SmartPLS.

Berdasarkan analisa dan pembahasan pada bagian sebelumnya maka dapat disimpulkan sebagai berikut :

1. Variabel Kualitas Sistem tidak berpengaruh signifikan terhadap Kepuasan Pengguna karena nilai signifikansi yang ditunjukkan oleh t-statistic hanya sebesar $\mathbf{0 , 8 5 9}$ yang lebih kecil dibandingkan dengan nilai t-tabel yaitu 1,68.

2. Variabel Kualitas Informasi berpengaruh signifikan terhadap Kepuasan Pengguna dengan nilai original sample sebesar $\mathbf{0 , 2 6 0}$ dan nilai signifikansi tstatistic sebesar 2,478 lebih besar dibandingkan dengan nilai t-tabel yaitu 1,68.

3. Variabel Perceived usefulness berpengaruh signifikan terhadap Kepuasan Pengguna dengan nilai original sample sebesar 0,679 dan nilai signifikansi tstatistic sebesar 5,739 lebih besar dibandingkan dengan nilai t-tabel yaitu 1,68.

4. Nilai R-square untuk variabel Kepuasan Pengguna yang dipengaruhi signifikan oleh variabel Kualitas Sistem, Kualitas Informasi, dan perceived usefulness dalam penelitian ini yaitu sebesar $\mathbf{0 , 8 4 6}$ atau 84,6\%. Hal ini berarti membuktikan bahwa variabel Kepuasan Pengguna mendapat pengaruh lain dari variabel diluar penelitian sebesar $\mathbf{1 5 , 4 \%}$.

\section{Bibliografi}

Afandi, Siti M. (2017). "Efektivitas Sistem Informasi Internet Banking BiPlus Terhadap Manfaat Bersih Pada PT. Bank UOB Indonesia." 
Vicky Arvianto, Wendi Usino.

Ali, Bejjar Mohamed, \& Younes, Boujelbene. (2013). The impact of information systems on user performance: an exploratory study. Journal of Knowledge Management, Economics and Information Technology, 3(2), 128-154.

Anuraga, Gangga, Sulistiyawan, Edy, \& Munadhiroh, S. (2017). Structural Equation Modeling-Partial Least Square untuk Pemodelan Indeks Pembangunan Kesehatan Masyarakat (IPKM) di Jawa Timur. Seminar Nasional Matematika Dan Aplikasinya, Surabaya.

Arikunto, Suharsimi. (2009). Manajemen Penelitian: Jakarta: Rineka Cipta. Anjaryani, WD.

Buana, IBGM, \& Wirawati, Ni Gusti Putu. (2018). Pengaruh kualitas sistem informasi, kualitas informasi, dan perceived usefulness pada kepuasan pengguna sistem informasi akuntansi. E-Jurnal Akuntansi Universitas Udayana, 22(1), 683-713.

Davis, Fred D. (1989)._Perceived usefulness, perceived ease of use, and user acceptance of information technology. MIS Quarterly, 319-340.

DeLone, William H., \& McLean, Ephraim R. (1992). Information systems success: The quest for the dependent variable. Information Systems Research, 3(1), 60-95.

DeLone, William H., \& McLean, Ephraim R. (2003). The DeLone and McLean model of information systems success: a ten-year update. Journal of Management Information Systems, 19(4), 9-30.

Fendini, Dian Septiayu. (2013). Pengaruh Kualitas Sistem dan Kualitas informasi terhadap Kepuasan Pengguna (Survei Pada Karyawan Pengguna Aplikasi Pelayanan Pelanggan Terpusat (AP2T) di PT. PLN (Persero) Area Malang). Jurnal Administrasi Bisnis, 4(1).

Hall, James A. (2001). Sistem informasi akuntansi.

Hanadia. (2017). Pengaruh Kualitas Sistem, Perceived usefulness dan Kualitas Informasi Terhadap Kepuasan Pengguna (Studi Kasus Terhadap Sistem Dashboard PDAM Tirta Raharja 2017). In EProceeding of Management, 2707-2714.

Haqiqi, Muhammad, \& Suwarno, Agus Endro. (2019). Pengaruh Kualitas Sistem Informasi, Kualitas Informasi, Dan Perceived usefulness Terhadap Kepuasan Pengguna Software Akuntansi (Studi Empiris Pada Perusahaan Yang Menggunakan Software Akuntansi Di Kecamatan Kartasura). Universitas Muhammadiyah surakarta.

Haryono, Siswoyo. (2016). Metode SEM Untuk Penelitian Manajemen dengan AMOS 22.00, LISREL 8.80 dan Smart PLS 3.0. PT Intermedia Personalia Utama. Jawa Barat.

Hussein, Ananda Sabil. (2015). Penelitian bisnis dan manajemen menggunakan Partial 
Analisis Pengaruh Kualitas Sistem Informasi, Kualitas Informasi dan Perceived Usefulness Terhadap Kepuasan Pengguna Aplikasi Olibsifrs (Psak) 71 (Studi pada Bank

Least Squares (PLS) dengan SmartPLS 3.0. Universitas Brawijaya.

Ilat, Veronica, Sabijono, Harijanto, \& Rondonuwu, Sintje. (2020). EVALUASI PENERAPAN PSAK 71 MENGENAI INSTRUMEN KEUANGAN PADA PT. SARANA SULUT VENTURA MANADO. Going Concern: Jurnal Riset Akuntansi, 15(3), 514-520.

Kartika, Nilam Dwi, \& Anton, Adnanti W. A. (2016). Analisis Kualitas Sistem Informasi, Perceived usefulness dan Kualitas Informasi Terhadap Kepuasan End User Software Akuntansi. SNA XI Lampung.

Marlina, Firda Tri. (2016). Pengaruh Kualitas Sistem Informasi Akuntansi Dan Kualitas Informasi Akuntansi Terhdadap Kepuasan Pengguna Pada Bank Syariah Di Kota Bandung.

Pawirosumarto, Suharno. (2016). Pengaruh kualitas sistem, kualitas informasi, dan kualitas layanan terhadap kepuasan pengguna sistem e-learning. MIX: Jurnal Ilmiah Manajemen, 6(3), 152864.

Popoola, Babatunde A., Chinomona, Richard, \& Chinomona, Elizabeth. (2014). The Influence of Information Quality, System Quality and Service Quality on Student's Self-Efficacy at Institutions of Higher Learning in South Africa. Mediterranean Journal of Social Sciences, 5(27 P2), 974.

Pratomo, Amalia dan. (2016). Pengaruh Kualitas Sistem Informasi, Kualitas Informasi dan Perceived usefulness Terhadap Kepuasan Pengguna Sistem Informasi Akuntansi di Rumah Sakit Mata Acendo Bandung. EProceeding of Management, 15-16. Bandung.

Putra, Ida Ayu Prabadewi dan Ida Bagus. (2019). "Pengaruh Kualitas Informasi, Kualitas Sistem Informasi, dan Perceived usefulness pada Kepuasan Pengguna SIMDA",.

Putra, Muhammad Reza Soekamto, \& Prasetyo, Eko. (2021). Analisis Kualitas Sistem Informasi Akuntansi, Perceived usefulness Terhadap Kepuasan Pengguna Pada Tanaya Realty di Kota Sidoarjo. JURNAL EKUIVALENSI, 6(2), 342-356.

Rahmawati, Dessy Ari. (n.d.). PENGARUH KUALITAS INFORMASI DAN KUALITAS SISTEM INFORMASI TERHADAP KEPUASAN SERTA KINERJA PENGGUNA SISTEM INFORMASI.

Rukmiyati, Ni Made Sri, \& Budiartha, I. Ketut. (2016). Pengaruh kualitas sistem informasi, kualitas informasi dan perceived usefulness pada kepuasan pengguna akhir software akuntansi (studi empiris pada hotel berbintang di provinsi bali). EJurnal Ekonomi Dan Bisnis Universitas Udayana, 5(1), 115-142.

Seddon, Peter B. (1997). A respecification and extension of the DeLone and McLean model of IS success. Information Systems Research, 8(3), 240-253. 
Vicky Arvianto, Wendi Usino.

Sekaran, Uma. (2011). Metodologi Penelitian untuk Bisnis, Edisi 4, Buku 1, Jakarta: Salemba Empat. Hal.

Sugiyono. (2012). Metode Penelitian Kuantitatif. 46-57.

Sumiyati, L., Yuliansyah, Yuliansyah, \& Dewi, F. G. (2013). The Effect of Information System Quality, Information Quality, and Perceived usefulness on Accounting Software User Satisfaction. Simposium Nasional Akuntansi, 16.

Tam, Carlos, \& Oliveira, Tiago. (2017). Understanding mobile banking individual performance: The DeLone \& McLean model and the moderating effects of individual culture. Internet Research. 